\title{
FARMING PATTERNS AND EXPORT GROWTH OPPORTUNITIES IN SOUTH CANTERBURY
}

B.W. PARKER

Senior Advisory Officer, MA F, Timaru

\section{LAND}

The wide diversity of soil, topography and climate enables South Canterbury's 2300 farm holdings to produce a wide range of livestock, arable and horticultural products. The 3 counties (Strathallan, Waimate and Mackenzie) cover a land area of nearly 1.4 million hectares stretching between the Rangitata River in the north to the Waitaki River in the south and the coast in the east to the southern divide in the west. Approximately $75 \%$ or 1 million hectares are farmable falling into land use capability classes I-7 (Table 1). Of this approximately 200,000 hectares or $20 \%$ are in land use classes 1-3 and can therefore be considered as potentially arable. The bulk of this land occurs on the coastal plain and easier downlands in the counties of Strathallan and Waimate. The balance of approx $8 \overline{8} 00$ ivu hectares or $80 \%$ are in land use classes 4-7 being divided between 600,000 hectares of high country and 200,000 hectares of downland. Over two-thirds of the high country lies in the Mackenzie county while the downlands which can be further divided into wet and dry occur in all counties between the coastal plain and the inland high country.

Table 1: LAND AREA (HECTARES) WITHIN LAND USE CAPABILITY CLASSES SOUTH CANTERBURY.

\begin{tabular}{lcccc}
\hline & \multicolumn{2}{c}{ Land Class } & Total Farmable & \\
Countv & $(\mathbf{1 - 3 )}$ & $\mathbf{( 4 - 7 )}$ & $\mathbf{( 1 - 7 )}$ & Total Land Area \\
\hline Waimate & 87979 & 248829 & 336808 & 358306 \\
Strathallan & 88415 & 131476 & $\mathbf{2 1 9 8 9 1}$ & 274863 \\
Mackenzie & 32839 & 433004 & 465843 & 744158 \\
Total South Canterbury & 209233 & 813309 & 1022542 & 1377327 \\
\hline
\end{tabular}

Soils range from Recent soils on the plains to Yellow-Grey Earths on the downlands to Yellow-Brown Earths in the high country. Annual rainfall varies from 500 to $600 \mathrm{~mm}$ on the coast and drier downlands to 750 to $850 \mathrm{~mm}$ on the wetter downlands. The inland high country can receive as little as $300 \mathrm{~mm}$ on the plains to as much as $1500 \mathrm{~mm}$ on the higher country.

\section{Table 2: LIVESTOCK TRENDS: SOUTH CANTERBURY}

\begin{tabular}{lcccc}
\hline Year (30th June) & 1976 & 1979 & 1982 & 1983 \\
\hline Total Stock Units (Million) & 3.81 & 3.80 & 4.22 & 4.01 \\
$\%$ Sheep & 77 & 83 & 84 & 86 \\
$\%$ Beef Cattle & 21 & 15 & 13 & 11 \\
Breeding Ewes (Million) & 2.3 & 2.46 & 2.70 & 2.68 \\
Beef Cows & 64800 & 59400 & 42800 & 36300 \\
Dairy Cows & 7600 & 6800 & 7100 & 10000 \\
Total Deer & & & 10600 & 11500 \\
\hline
\end{tabular}




\section{LAND USE}

Livestock numbers peaked in 1981 (Table 2) at around 4.2 million stock units but since then and due mainly to 2 years of drought have declined to around 4 million. Sheep make up $86 \%$ of total stock units currently farmed including 2.6 million breeding ewes on 1900 sheep properties. Beef cattle numbers have experienced a dramatic decline from $25 \%$ of total livestock units in 1976 to only $11 \%$ now. Currently dairy cattle and deer are two growth sectors in the livestock industry but at present represent only 75,000 and 17,000 stock units respectively - less than $3 \%$ of total stock units.

The Arable sector currently utilises around 50,000 hectares of the 200,000 hectares of class 1 to 3 land on the plains and easy downlands. Cereal production mainly wheat and barley predominates with 37,000 hectares under crop last season after a dramatic $133 \%$ increase in the barley area (Table 3 ). Small seeds, mainly white clover and ryegrass occupy 10,000 hectares. Other crops include peas, beans, potatoes, carrots, onions and buttercup squash. A small horticultural sector (300 hectares) produces mainly berryfruit and asparagus but a pipfruit industry is in its infancy.

Table 3: ARABLE TRENDS: SOUTH CANTERBURY

\begin{tabular}{lrrrr}
\hline Year & 1976 & 1979 & 1992 & 1993 \\
\hline Barley (Hectares) & 12500 & 12500 & 12000 & 28000 \\
Wheat & 17000 & 12000 & 8300 & 8200 \\
Small Seeds & 8500 & 8400 & 9000 & 10000 \\
Other & 5500 & 5000 & 5000 & 5000 \\
Total & 43500 & 37900 & 34300 & 51200 \\
\hline
\end{tabular}

\section{EXPORT GROWTH OPPORTUNITIES}

With the diversity of its land resource and with an export port at is doorstep the potential for growth in agricultural exports from South Canterbury is both realistic and considerable. This increase in output and the product mix will depend on market forces and irrigation development.

With present technology and without any further assistance from irrigation the livestock sector has the capacity to expand output by $60 \%$ when measured by the difference between the performance of our top farmers and present levels of production (Table 4). This assessment was made by MAF advisers during the MOWD Land Resource Inventory exercise carried out in 1981 which collated production levels on a land use capability class basis for each county over the country.

The attainment of this growth potential in livestock production which is equivalent to around $\$ 80$ million at current farm gate prices will depend on:-

* Sustaining adequate profitability at the farm gate.

- Improving the management ability of the farm operator.

- Developing effective drought strategies.

Table 4: LIVESTOCK GROWTH POTENTIAL SOUTH CANTERBURY (MILLION STOCK UNITS)

\begin{tabular}{lcccc}
\hline & Waimate & Strathallen & Mackenzie & Total \\
\hline Present Level & 1.6 & 1.35 & 1.05 & 4.0 \\
Top Farmer Level & 2.37 & 2.13 & 1.90 & 6.4 \\
Percent Increase & 47 & 57 & 81 & 60 \\
\hline
\end{tabular}


Farmers have a high propensity to re-invest cash surplus's in farm development. Adequate profitability therefore means sufficient income for ploughback which at 1984 values would need to be above $\$ 2 /$ s.u. on meat and wool farms.

Improving the ability of the farm operator is perhaps one of the major constraints to increasing production in agriculture. In the past the inefficient operator has been continually 'propped up' by a succession of government support measures. A recent statement by the Minister of Agriculture suggests that this may now not occur - the non performer will not survive.

The confidence for farmers to invest in programmes to increase productivity can be seriously eroded by the risk of drought. Drought strategies may need to be introduced in farming systems. Those applicable to South Canterbury generally fall into 2 categories - those that can reduce feed demand e.g. buffer mobs that can be sold early such as increasing the proporiton of ewe hoggets or farming a proportion of the ewes as a flying flock and those that can increase feed supply e.g. introducing more drought tolerant species such as Matua prairie grass, Roa tall fescue and Wana cocksfoot and tree lucerne and changing to a conservation system based on wilted fine chop silage. Despite the severe consequences of the recent drought there appears to have been little on farm activity to introduce these strategies into livestock systems.

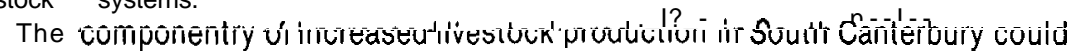
take a number of forms. It is vital therefore that long term market signals are both clearly and correctly identified. Possible opportunities include -

- Increasing the production of fine wool: direct drilling programmes have the potential to increase stock numbers in the Mackenzie by nearly 0.4 million stock units alone.

* Increasing the production of crossbred wool: Crossbred wool production per sheep stock unit is low when compared with the North Island. Increasing the ratio of ewe hoggets farmed from the current average of $23 \%$ of ewe numbers to $35 \%$ would increase wool produced on average from $5 \mathrm{~kg}$ to $6 \mathrm{~kg}$ per sheep stock unit wintered. Increasing numbers in this way would do less to compound the sheep meat problems and would also provide greater drought flexibility.

- Dairy production has the processing capacity to treble production and it is anticipated that this increase will eventuate.

- With the increase in the dairy herd a dairy beef industry should follow.

- Deer numbers are increasing as fast as breeding allows. Only a fall in the vension price to below $\$ 5$ a $\mathrm{kg}$ will slow this trend.

Table 5: COMPARATIVE RETURNS STOCK AND CROP

\begin{tabular}{llc}
\hline & $\begin{array}{c}\text { Gross Margin } \\
\text { Dryland }\end{array}$ & $\begin{array}{c}\text { (\$) Hectare } \\
\text { Irrigated }\end{array}$ \\
\hline Sheep & 220 & 400 \\
Beef & 180 & 320 \\
Deer (a) & 900 & 1600 \\
$\quad$ (b) & 360 & 640 \\
Dairy & & 1000 \\
Barley & 600 & 1000 \\
Pipfruit & & 7000 \\
\hline
\end{tabular}

\section{ARABLE OPPORTUNITIES}

The arable sector using only 50,000 hectares of a potential land resource of around 200,000 hectares obviously has the scope to expand if the markets are there. 
Barley, the 'best bet' at present, is in an active growth phase. This could be consolidated into a longer term trend for South Canterbury. The potential is there to more than double production by expanding the area and increasing crop yields. If current relativity continues there is a very real opportunity to increase returns per hectare by $1 \frac{1}{2}$ to 2 times sheep on many non irrigated properties (Table 5). Of the livestock systems only deer and dairying can compete with barley. The deer policy(b) based on venison sales only, gives a truer indication of an export return not influenced by a high internal demand for live female animals.

\section{IRRIGATION}

The need to intensify Land use to justify the costs of irrigation development $(\$ 1000-\$ 1500 / \mathrm{ha})$ will accelerate the swing from stock to crop if proposed irrigation schemes proceed. At present 23,000 hectares can be irrigated in South Canterbury of which 18,500 are under government schemes. Future possibilities which could increase the irrigated area by 32,000 hectares include 11,500 hectare under investigation at present. Diversification and intensification must follow irrigation development. Horticulture and particularly the development of a sizeable pipfruit industry could become a significant part of the intensification process. A wide range of agricultural growth opportunities are available to South Canterbury farmers. It will be important that these are export orientated and market led. It will be essential that the respective industries develop agricultural policies to allow the true long term market signals to reach the farmer.

\section{REFERENCES}

NWASCO "New Zealand Land Resource Inventory Worksheets", 1:63360. National Water and Soil Conservation Organisation, Wellington, New Zealand.

Department of Statistics "Agricultural Statistics" 1976-1982.

Gross Margins For South Canterbury. Advisory Services Division (MAF) Publication 1984. 